\title{
Establishing landuse/cover change patterns over the last two decades and associated factors for change in semi arid and sub humid zones of Tanzania
}

\author{
Amos Enock Majule \\ Institute of Resource Assessment (IRA), University of Dar es Salaam, Dar es Salaam, Tanzania; \\ amajule@ira.udsm.ac.tz, amajule@gmail.com \\ Received 11 June 2013; revised 29 July 2013; accepted 15 August 2013 \\ Copyright (C) 2013 Amos Enock Majule. This is an open access article distributed under the Creative Commons Attribution License, \\ which permits unrestricted use, distribution, and reproduction in any medium, provided the original work is properly cited.
}

\begin{abstract}
This study investigated landuse cover change patterns and established potential environmental and social factors that have contributed to changes in two zones namely sub humid and semi-arid found in southern highland and central parts of Tanzania respectively. The overall objective was to understand change patterns; the process evolves and clearly isolates various factors that have contributed to the changes over the last 20 years. A total of four villages, two in each zone were involved whereby historical land use cover changes were analysed using remote sensing techniques. To do so satellite imageries for 1991 and 2011 and those of 1986 and 2009 for sub humid and semi-arid zones respectively. Factors for changes were established through focus group discussions (FDGs) with a total of 80 participants (20 per village) and household $(\mathrm{HH})$ interviews subjected to $10 \%$ of the total number of $\mathrm{HH}$ per village. Both woodlands and bush lands decreased in the expense of mixed farming in both sub humid and semiarid zones to a maximum of $121 \%$ and $146.8 \%$ respectively. Wetland farming also increased particular in sub humid zone. In general, both environmental and social factors were found to have contributed to LUCC in various magnitudes in both zones. Such observed change on landuse will continue and it is recommended that there is a need to have in place and implement proper landuse plan also have capacity building programs on climate and land management issues for both livelihood and ecosystem sustainability need to in place.
\end{abstract}

Keywords: Agriculture; Climate Change; Landuse; Mixed Farming; Woodlands; Vinyungu

\section{INTRODUCTION}

The majority of communities living in rural areas of Sub-Sahara Africa (SSA) depend their livelihood on the utilization of natural resources particularly from forest, woodlands, wetlands and agricultural land for crops and livestock production [1]. Such resources have been dwindling in many places but in some places where sustainable management are in place and not transformed to other emerging new landuse (LU) both non wood and wood products play a significant role in terms of providing both products and other services [2,3]. A number of studies in the region have reported for example how different livelihood system interacted with natural resources in the past where natural resources were not under pressure and what is recently happening [4,5]. For example over the last 50 years ago in East African ecological gradients of for example Mounts Kenya and Kilimanjaro natural resources were used in a sustainable way because population was low in such areas and economical pressure was low [6,7]. Also during that time much of the land was suitable to support various crops and livestock production and hence there was no much need to acquire new land. Apart from forest resources other landuse types such as woodlands, wetlands, crop lands, and bush lands supported different ecosystems which then to a large extent maintained both social and natural systems [3].

Over the last 30 years a situation has changed significantly and this is likely to continue changing if some measures are not taken. Due to changing landuse in different agro-ecological systems in Tanzania, different new landuse cover (LUC) types have emerged with various 
implications to both community livelihoods and upon environment [8,9]. Various reasons have been proposed for observed changes but yet more studies are still needed since factors for change are sometime spatially determined. For example there are limited reports which show that long term climate change may result to landuse cover change due to changes in rainfall patterns and rise in temperature favouring other land uses to emerge with consequences on community livelihoods [10]. On the other hand, [11] made an attempt to link the impact of various environmental factors including climate change and landuse and findings showed that the link is somehow indirect which suggests further investigation.

On the other hand, in Tanzania a study by [12] has revealed that there has been an increase in cultivated land due to population increase and investment in agriculture sector. In addition, a study by [13] found the root causes of the land use and cover changes that have taken place on the southern slope of Mount Kilimanjaro are many and multifaced. They include demographic factors, colonial and post-independence government policies, institutional factors, legislation, as well as socio-cultural, economic and environmental factors. [14] added two more factors on the causes of agricultural land expansion in East Africa namely; access to markets and changes in land tenure arrangement. Further more studies by William $[15,16]$ revealed that liberalized economic relations, such as free trade agreements and economic globalization change people's relations to the physical environment hence induce changes in LU. The intensity and scale of land use change has increased drastically in recent decades, partly due to expansion of farmlands, settlements and climate stresses that force agro-pastoral communities to search for virgin pastures and croplands.

Basing on these trends, land use cover change and degradation of the natural resources such as land, water, forests, woodlands, grasslands and wildlife in Tanzania have been common in various ecosystems in particularly slopes of Kilimanjaro [13]; Usangu basin and slopes of Mount Rungwe in the volcanic region $[8,9,17]$ and thus exposing rural communities to vulnerable ecosystems $[18,19]$. Although many studies have been able to establish changing landuse cover types at a wide scale in various agro ecological systems. Very few of them have been able to isolate various biophysical and social factors that have contributed to such changes and where the changes observed have positive impacts. The overall aim of this study was to assess and analyse different landuse cover types over the last 2 decades in two agro ecological zones of Tanzania characterised by semi humid and semi arid conditions. The study also made an attempt to isolate both biophysical and social factors that have played a significant role in causing landuse cover change.

\section{METHODOLOGY}

\subsection{Description of the Study Area}

The study was conducted in two climatic zones namely sub humid and semi arid zones. In sub humid zone the study was conducted in Mufindi district in Iringa region which forms the part of the southern highland zone of Tanzania (Figure 1). Mufindi is one of four districts in Iringa Region located in Southern highlands of Tanzania lying between $8^{\circ} 00^{\prime}$ and $9^{\circ} 15^{\prime}$ South and longitude $34^{\circ} 35^{\prime}$ to $35^{\circ} 55^{\prime}$ East. The district is situated about $80 \mathrm{~km}$ from Iringa Municipality and is bordered by Iringa district to the North, Morogoro region to the East, Njombe region to the South and Mbeya region to the West. The area received a minimum and maximum rainfall of 1000 and $2000 \mathrm{~mm} / \mathrm{yr}$ respectively and both average annual minimum and annual temperatures remains to be $16^{\circ} \mathrm{C}$ and $23^{\circ} \mathrm{C}$ on average respectively [20].

In the semi arid zone this study was carried out in Nzega district in Tabora region, Tanzania in Undomo and Mbutu villages (Figure 2). Nzega is one of the six districts of Tabora region, which covers the area of 9226 $\mathrm{km}^{2}$, and lies between longitudes $36^{\circ} 30^{\prime}$ and $33^{\circ} 30^{\prime} \mathrm{E}$ and latitudes $3^{\circ} 45^{\prime}$ and $5^{\circ} 00^{\prime} \mathrm{S}$. The District is characterized by unimodal type of rainfall, which falls between November and April. The distributions are unreliable with annual average usually less than $700 \mathrm{~mm}$. The temperature ranges from $28^{\circ} \mathrm{C}$ to $30^{\circ} \mathrm{C}$. The highest temperature is experienced in October just before onset of rainfall. A dry spell between normally occurs between mid January and February [19].

\subsection{Historical Analysis of Land Use Cover Changes}

Processing and analysis of remote sensing and GIS data on establishing change detection (land cover or land use changes in the sample study wards involved five key procedures: image interpretation, image classification, image digitization, overlying analysis and generalization of error matrix. In this case overlaying analysis was employed so as to derive new information from two land cover layer covering the same area. The process was done by using satellite images available of year 1986 and 2009 for semi arid zone and that of 1991 and 2011 for sub humid zone to discover land cover changes based on the computed area. Change detection for each landuse category was then performed using standard procedure used by [8].

\subsection{Establishing Factors for Landuse Cover Change}

In order to establish factors of change and implications of new emerging land upon environment and community 


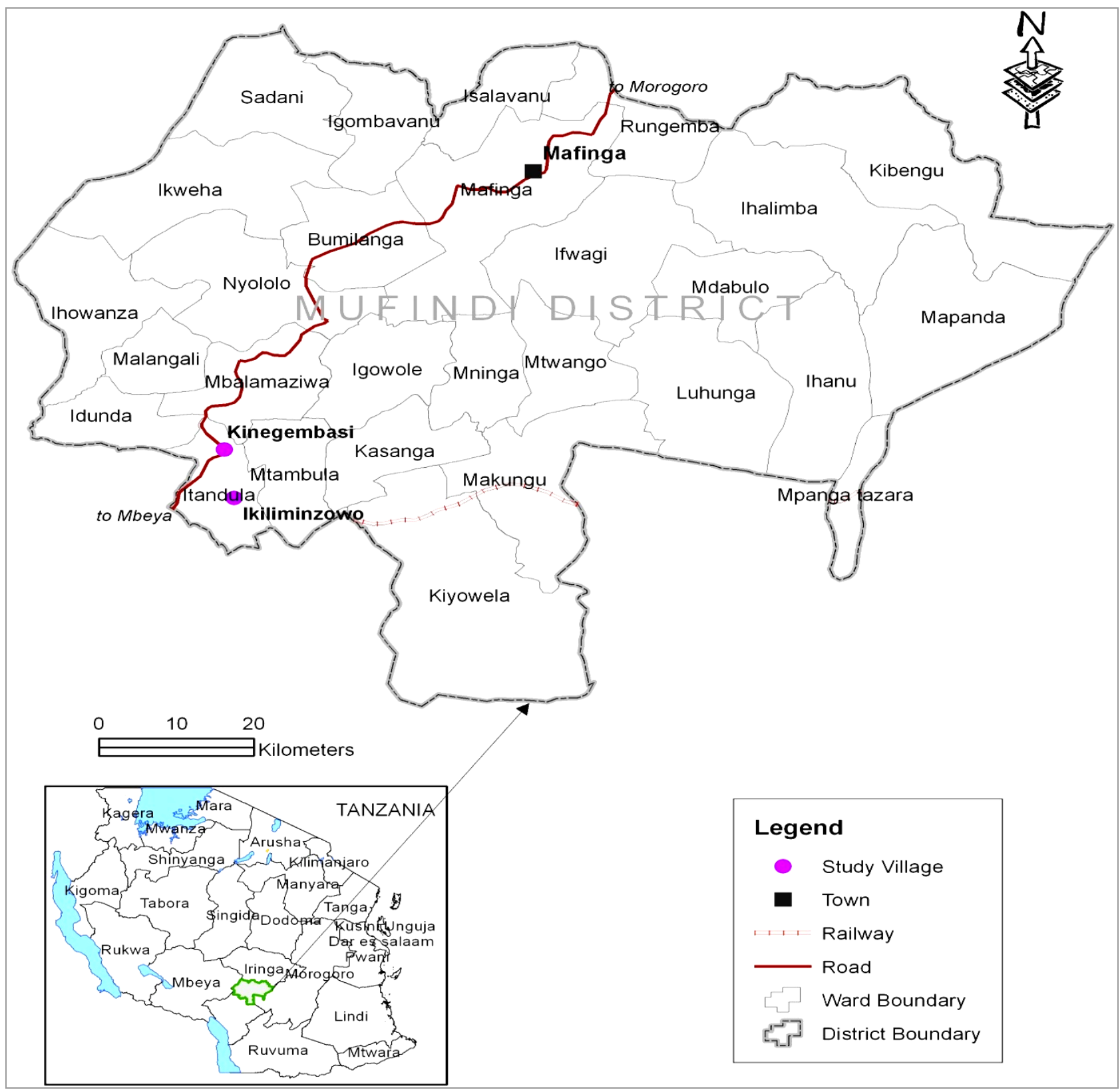

Figure 1. Location of study area and villages in sub humid zone, Tanzania.

livelihoods data were collected through literature review and through focus group discussions in respective study villages using a checklist administered to a total of 20 people per village strategically selected. This was supplemented by information collected through household interviews in respective zones per villages presented in Tables 1 and 2. In this case a checklist with both open and closed questions was adopted.

A similar approach was also used by [18] when studying land degradation in semi arid area of central Tanzania. Where the information was not satistisfactory on certain issues discussion with key informants was also employed. Both qualitative and quantitative data analysed using the
Statistical Package for Social Science (SPSS) software version 16.0 and spread sheet and results were presented in different forms including Tables and Bar charts.

\section{RESULTS AND DISCUSSION}

\subsection{Historical Analysis of Landuse Cover Changes in Two Zones}

\subsubsection{Sub-Humid Case Study Zone}

Major landuse/cover types found in the study area is presented in Tables $\mathbf{3}$ and $\mathbf{4}$ for Kimilinzowo and Kinegembasi villages respectively. In Kimilinzowo (Table 3) results indicate that there has been a substantial 


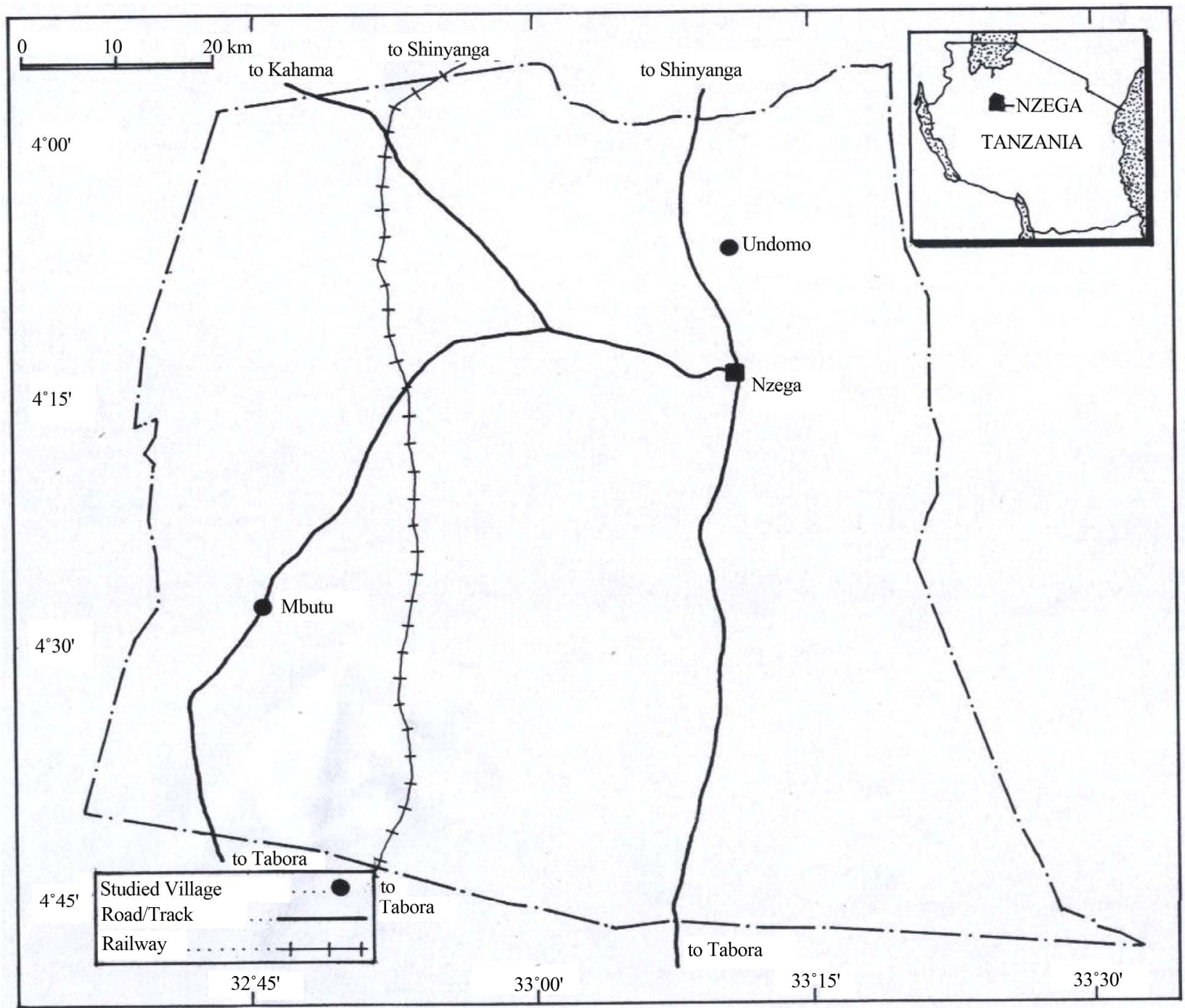

Figure 2. Location of study area and villages in semi arid zone.

Table 1. Distribution of household sample size in semi arid zone.

\begin{tabular}{cccc}
\hline Village name & Number of households & $\begin{array}{c}\text { Number of } \\
\text { respondents }\end{array}$ & \% of sample \\
\hline Mbutu & 512 & 52 & 10 \\
Undomo & 570 & 57 & 10 \\
Total & $\mathbf{1 0 8 2}$ & $\mathbf{1 0 9}$ & $\mathbf{1 0}$ \\
\hline
\end{tabular}

Table 2. Distribution of household sample size in sub-humid zone.

\begin{tabular}{cccc}
\hline Village name & Number of households & $\begin{array}{c}\text { Number of } \\
\text { respondents }\end{array}$ & \% of sample \\
\hline Kinegembasi & 560 & 50 & 9.2 \\
Kimilinzowo & 762 & 70 & 9.2 \\
Total & 1322 & 120 & 18.4 \\
\hline
\end{tabular}

Source: Ward office (2012). change of land-use/cover in the following manner; bush land with scattered crop land has decreased by $16 \%$; bare soil has declined by $3 \%$. On the other hand closed woodland has decreased by $11 \%$ while cultivated land has increased by $121 \%$. Other landuse cover types in particular grassland with scattered crop land have increased by $5 \%$, open grassland has decreased by $6 \%$ and open woodland has increased by $10 \%$ while woodland with scattered cropland has also decreased by $10 \%$. In general there is no natural forest detected suggesting that deforestation occurred in the area beyond 1991 and what is happening is dynamic change of other landuse cover types on the expense of expanding crop land in the area.

It is evident that open grasslands which mostly were wetlands has decreased due to expansion in valley bottoms cultivation traditionally known as vinyungu as these are considered as adaptation strategy to drought due to increasing rainfall unreliability [20,21]. Analysis 
Table 3. Landuse cover change analysis in Kimilinzowo.

\begin{tabular}{|c|c|c|c|c|}
\hline \multirow{3}{*}{ Land use/cover types } & \multicolumn{2}{|c|}{ Years } & \multicolumn{2}{|c|}{ Changes } \\
\hline & 1991 & 2011 & $1991-2011$ & $1991-2011$ \\
\hline & Area (ha) & Area (ha) & Change Index (ha) & Change $(\%)$ \\
\hline Bush land with scattered cropland & 2378 & 1435 & -943 & -39.6 \\
\hline Bare soil & 194 & 000 & -194 & -100 \\
\hline Closed woodland & 437 & 404 & -33 & -7.6 \\
\hline Cultivated land & 1053 & 2322 & +1269 & 120.5 \\
\hline Grassland with scattered cropland & 802 & 1125 & +323 & 40.3 \\
\hline Open grassland & 535 & 146 & -389 & -72.7 \\
\hline Open woodland & 000 & 582 & +582 & +100 \\
\hline Woodland with scattered cropland & 615 & 000 & -615 & -100 \\
\hline Total & 6014 & 6014 & & \\
\hline
\end{tabular}

Table 4. Landuse cover change analysis in Kinembasi village.

\begin{tabular}{ccccc}
\hline & \multicolumn{3}{c}{ Years } & \multicolumn{2}{c}{ Changes } \\
\cline { 2 - 5 } Land use/cover types & 1991 & 2011 & $1991-2011$ & $1991-2011$ \\
\cline { 2 - 5 } & Area (ha) & Area (ha) & Change Index (ha) & Change (\%) \\
\hline Bush land with scattered cropland & 1133 & 964 & -169 & -14.9 \\
Closed woodland & 10 & 16 & 6 & 60.0 \\
Cultivated land & 612 & 1293 & 681 & 111.3 \\
Grassland with scattered cropland & 1638 & 319 & 669 & -1319 \\
Open grassland & 0 & 669 & 46 & 100.0 \\
Open grassland seasonally inundated & 99 & 145 & 85 & 46.5 \\
Open woodland & 571 & 656 & & 14.9 \\
Total & $\mathbf{4 0 6 3}$ & $\mathbf{4 0 6 2}$ & & \\
\hline
\end{tabular}

of satellite image for Kinegembasi village on landuse/ cover changes for the same period did not differed substantially if you compare with that of Kiliminzowo village (Table 4). For example, bush land with scattered crop land also decreased by $14.9 \%$ while bare soil, closed woodland have decreased in the order similar to that of Kiliminzovo. It was also interesting to note that cultivated land has increased by $111.3 \%$ in the order similar to that of Kiliminzowo village. Other land cover types including grassland with scattered crop land decreased by $80.5 \%$ suggesting a conversion to crop land particular wetlands. Finding revealed that open woodland was not significant in such area (Table 4) although it increased by $14.9 \%$ suggesting positive impact of conservation initiatives.

\subsubsection{Semi Arid Case Study Zone}

Tables 5 and 6 present an analysis of historical lan- duse cover change for selected case study villages in semi arid zone. In general there are more landuse cover types as compared to case study villages in sub humid zone (10 vs 7 ) and this suggests that there a diversification in landuse practices in semi arid zones as compared to sub humid. This is true because in semi arid zones people are sparsely populated allowing them to diversify their economic activities due large land available as compared to sub humid zones which are densely populated and have limited land. Table 5 shows that dense and open bush lands, bushed grass land have decreased by $100 \%, 96.5 \%$ and $94.4 \%$ respectively on the expense of land under mixed cropping which increased by $64.9 \%$. In general this indicates a significant expansion of agriculture activities in the area due to high demand of food crops by people. The area is very potential for food production in the region due to high fertility nature of vertisol which dominate the area. 
Table 5. Landuse cover change analysis for Mbutu case study area.

\begin{tabular}{|c|c|c|c|c|}
\hline \multirow{3}{*}{ Land use/cover types } & \multicolumn{2}{|c|}{ Years } & \multicolumn{2}{|c|}{ Changes } \\
\hline & 1986 & 2009 & $1986-2009$ & $1986-2009$ \\
\hline & Area (ha) & Area (ha) & Change Index (ha) & Change (\%) \\
\hline Dense Bushland & 4913 & 0 & -4913 & -100 \\
\hline Open Bushland & 27,227 & 954 & $-26,273$ & -96.5 \\
\hline Open Bushland (Lowland) & 43 & 366 & 323 & 751.2 \\
\hline Mixed Crop Land & 68,332 & 112,664 & 44,332 & 64.9 \\
\hline Bushed Grassland & 23,007 & 1287 & -21720 & -94.4 \\
\hline Bushed Grassland Seasonally Inundated & 283 & 0 & -283 & -100 \\
\hline Open Grassland & 9886 & 4117 & -5769 & -58.4 \\
\hline Open Grassland Seasonally Inundated & 269 & 416 & 147 & 54.6 \\
\hline Wooded Grassland & 2012 & 4146 & 2134 & 106.1 \\
\hline Water & 34 & 243 & 209 & 614.7 \\
\hline Mixed Crop land-Lowland & 849 & 7786 & 6937 & 817.1 \\
\hline Settlement & 260 & 216 & -44 & -16.9 \\
\hline Closed Woodland & 121 & 459 & 338 & 279.3 \\
\hline Open Woodland & 2902 & 7484 & 4582 & 157.9 \\
\hline Totals & 140,138 & 140,138 & & \\
\hline
\end{tabular}

Table 6. Landuse cover change for Undomo case study.

\begin{tabular}{|c|c|c|c|c|}
\hline \multirow{3}{*}{ Land cover types } & \multicolumn{2}{|c|}{ Years } & \multicolumn{2}{|c|}{ Changes } \\
\hline & 1986 & 2009 & 1986-2009 & 1986-2009 \\
\hline & Area (ha) & Area (ha) & change Index (ha) & Change (\%) \\
\hline Dense Bushland & 0 & 178 & 178 & 100 \\
\hline Open Bushland & 943 & 861 & -82 & -8.7 \\
\hline Open Bushland-Lowland & 635 & 0 & -635 & -100 \\
\hline Mixed Cropland & 2619 & 6464 & 3845 & 146.8 \\
\hline Bushed Grassland & 2611 & 245 & -2366 & -90.6 \\
\hline Bushed Grassland Seasonally Inundated & 262 & 278 & 16 & 6.1 \\
\hline Open Grassland & 1227 & 0 & -1227 & -100 \\
\hline Open Grassland Seasonally Inundated & 2168 & 0 & -2168 & -100 \\
\hline Wooded Grassland & 486 & 1134 & 648 & 133.3 \\
\hline Water & 275 & 34 & -241 & -87.6 \\
\hline Settlement & 67 & 58 & -9 & -13.4 \\
\hline Closed Woodland & 1332 & 724 & -608 & -45.6 \\
\hline Open Woodland & 1877 & 4526 & 2649 & 141.1 \\
\hline Totals & 14,502 & 14,502 & & \\
\hline
\end{tabular}


Other landuse cover change of interest is an increase of both closed and open woodlands suggesting that there is a positive response towards conservation of woodlands due to various campaigns including REDD+ interventions and presence of a forest reserve. FGD revealed that there has been an increase of cultivation in wetlands and this is shown by a reduction of both grassland including seasonally inundated areas (Table 5). At Undomo Village (Table 6) patterns and trend on landuse cover change is quite similar to that reported for Mbutu village but with the exception of decreasing area under closed wood land. In general the land area is also small but this does not necessarily affect the pattern on LUCC observed.

The area under mixed cropping (Table 6) has increased on the expense of other landuse types due to various factors. It also apparent that water bodies has decreased and this was explained to be due to drying and lack of dams as compared to Undomo where there is a number of artificial dams.

\subsection{Factors for Land Use Cover Change}

\subsubsection{Environmental Related Factors}

To discuss environmental factors that have contributed to landuse cover change in case study zones one should consider both driving forces and the process it self. Various scholars have suggested that poverty, changes in policies and strategies are among the key driving forces to landuse cover change (LUCC). Findings showed that in all four case study villages three major wealth groups namely the rich, middle and poor groups are common and their distribution at village level ranged on average in the order of $10 \%, 30 \%$ and $60 \%$ for the rich, the middle and the poor respectively. It was clearly noted that the majority of people are poor and most of them live under poverty and this has contributed to degradation or natural resources contributing to LUCC. It was also clearly revealed that changes and introduction of new polices in the country contributed to LUCC changes for example the introduction of villagilization policy in Tanzania in mid 1970's whereby people were clustered in villages called "Ujamaa" or "live close together" contributed to deforestation in new areas where they moved into for settlement and opening of new farms. A similar explanation for LUCC in semi arid areas of Tanzania has been documented by $[8,18]$ for sub humid zone.

Environmental change in particular changing rainfall pattern and other rain related factors are shown in Figure 3 for semi arid zone were found to have contributed directly or indirectly to LUCC. Similar observations were also reported for sub humid zone where by $81 \%$ of the total respondents indicated so. However $19 \%$ of responded were not able to clearly the pattern and trend of rainfall some perceiving that it has increased. This observation is not surprising and it could be explained in terms of existing spatial variability of rain which is common in such areas.

Increasing temperature was also among factors mentioned during FGD that has contributed to LUCC in both sub humid and semi arid zones. In this case increasing temperature over decades was perceived by communities in all case study villages and this has been validated by empirical data on long term temperature trends by both Gwambene [17] and Kaijage [22] sub humid and semi arid zones respectively. A snap short on communities' perception with regard to temperature pattern at local level is shown in Figure 4.

In general the majority of communities reported that temperature has increased over that last 20 years and this trend is increasing. A paper by [19] provides a detailed analysis on the implication of both increasing temperature and changing rainfall pattern on both crops and livestock production. It is evident from the paper that crop pests and diseases have increased leading declining crop by nearly $40 \%$ over the last 20 years. Livestock production has also decreased and farmers by clearing woodlands and other LUC with understating that new land is fertile and can compensate loss incurred. In reality declining crop and livestock productivity could be associated with more than one factors and this calls for capacity building to farmers through research and training.

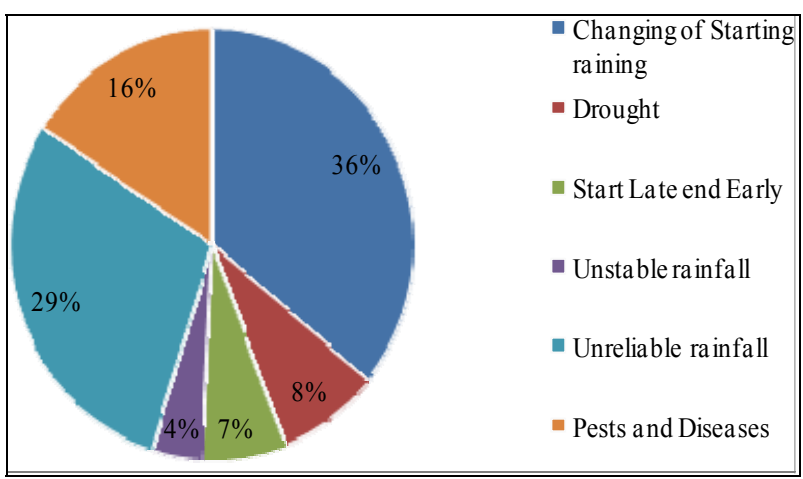

Figure 3. Rainfall related factor for LUCC in semi arid zone.

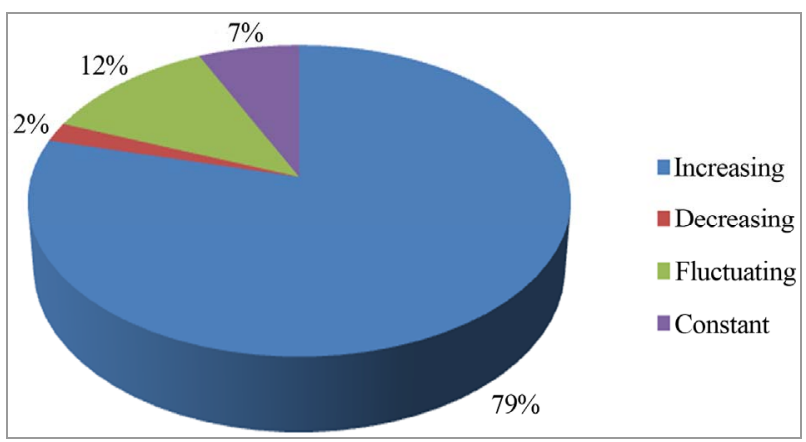

Figure 4. A snap shot of communities' perception on temperature trend in semi arid zone. 
Reported by $80 \%$ of the respondents was declining soil fertility in most dry land areas and this has forced farmers to open new areas which are more fertile particularly in semi arid areas. In sub humid zones due land scarcity a tendency has been to expand wetland to take advantage of moisture and accumulated soil fertility and this allow multiple crops and vegetable to be grown and it has been considered to be an adaptation option. Similar cases were also reported by individuals who participated in FGDs in both zones. Kiunsi and Meadow [2] also observed a similar case when studying land management issues in Monduli, Tanzania.

\subsubsection{Socio-Economic Related Factors}

Findings from household interview indicated that most of the people migrated in the study villages due to various reasons mainly being due to agricultural activities and following up their relatives as presented in Table 7. The role of agricultural expansion on landuse cover change is not surprising since it has also been reported by $[23,24]$.

Migration of people in case study villages to follow their relatives and marriages is among major factors contributing to increased human population and hence pressure on natural resources (Table 7). There are also those who migrated for other social economic related activities including looking suitable land with pasture for livestock keeping, seeking employment and other business opportunities. This also contributed to population increase in case study areas and hence LUCC.

\subsubsection{Demographic Factors}

Of importance in this study was an increase on human population at the rate of $4.5 \%$ and $3.2 \%$ respectively in sub humid and semi arid zone. This has increased pressure on natural resources in both zones resulting changes on landuses. In semi arid zone it was found that about $53 \%$ of the HH were Sukuma whereby $40 \%$ were Nyamwezi in tribes. The two tribes are native and commonly found in most parts of the region. Other ethnic

Table 7. Social economical reasons for in migration in study areas in $\%$ per zone.

\begin{tabular}{|c|c|c|c|}
\hline Major reasons & Sub humid & Semi arid & Mean \\
\hline Search for agricultural crop land & 38.5 & 60.0 & 49.0 \\
\hline Looking for new business opportunities & 7.5 & 9.0 & 8.25 \\
\hline New employment opportunities & NA & 9.0 & 9.0 \\
\hline Look for pasture land & NA & 2.0 & 2.0 \\
\hline Following relatives and marriages & 44.0 & 20.0 & 32.0 \\
\hline Total & 100 & 100 & 100 \\
\hline
\end{tabular}

NA: Not Applicable. groups constituting 7\% were found to be Gogo, Rangi, Nyakyusa and Nyiramba which originated from neighbouring regions.

\section{CONCLUSION}

Land use cover types differs in numbers and sizes in both sub humid and semi arid zones being larger in size and more in semi arid zone. However both cover and use types have changed over the last 20 years into different directions to absorb shock associated with both environmental changes and social economic, demographic and other related demands which are also growing. It is evident that climate change which is also triggering other factors such as land degradation has played a significant change and this is coupled by migration of people into new potential areas suitable for agriculture which was found to be expanding and being intensified. Two recommendations can be made. One is to have proper landuse plan such areas and implement them and second is to design and implement proper capacity building programs on climate and land management issues for both livelihood and ecosystem sustainability.

\section{ACKNOWLEDGEMENTS}

The author wishes to thank CORUS through the Rungwe Environmental Scientific Observatory Network and Rockefeller Foundation for providing financial assistance to undertake this important study. The University of Dar es Salaam management is thanked for granting permission to researchers to implement this study. Tabora and Iringa regions authority is thanked for allowing this study to be conducted in their regions. All technicians at GIS laboratory working at the Institute of Resource Assessment are thanked their analytical work. Finally I would like to thank research assistants namely Nassib Muzo and Lucy Kassian for their assistance on data collection in the field.

\section{REFERENCES}

[1] Adger, W.N., et al. (2007) Successful adaptation to climate change across scales. Global Environmental Change, 15, 77-86.

[2] Kiunsi, R.B. and Meadow, M.E. (2006) Assessing land degradation in the Monduli District, northern Tanzania. Land Degradation Development Journal, 17, 509-525. http://dx.doi.org/10.1002/ldr.733

[3] Majule, A.E., et al. (2009) Natural resource contribution to community livelihoods. Experience from selected case studies in Tanzania. Dar es Salaam University Press LTD, Dar es Salaam.

[4] Benard, F.E., et al. (1989) Carrying capacity of the eastern ecological gradient of Kanya. National Geographic Research, 5, 399-421.

[5] Campbel, D., et al. (2003) Root causes of land degradation in the Loitoktok area, Kajiado. LUCID Working Paper No. 19, International Livestock Research Institute, Nai- 
robi.

[6] Maitima, M.J., et al. (2009) The linkages between land use change, land degradation and biodiversity across East Africa. African Journal of Environmental Science and Technology, 3, 310-325.

[7] Majule, A.E., et al. (2009) Ecological gradients as a framework for analysis of land use change in East Africa. African Journal of Ecology, 47, 55-61. http://dx.doi.org/10.1111/j.1365-2028.2008.01050.x

[8] Muganyizi, J.M. (2009) Land use changes within agricultural systems and their implications on food security in Rungwe district, Tanzania. M.Sc Dissertation, University of Dar es Salaam, Dar es Salaam.

[9] Majule, A.E., et al. (2010) Underlying threats on forest reserves in Tabora Region, Western Tanzania: The case of Igombe River and Simbo forestry reserves. Journal of Studia Universtatis Babes-Bolyai, pp. 137-150.

[10] IPCC (2007) Working group II fourth assessment report. Climate change: Climate change impacts, adaptation and vulnerability. http://www.ipcc.ch/SPM6avr07

[11] Muzo, N. (2012) Climate change and its impacts on agricultural land use practices in selected villages of Nzega District, Tanzania. MSc. Dissertation, Dar es Salaam University Press, Dar es Salaam.

[12] FAO (2008) The state of food and agriculture, biofuels prospects, risks and opportunities in Tanzania. FAO, Rome.

[13] Mbonile, M.J., et al. (2003) Land use change pattern and root causes on the slope of mount Kilimanjaro, Tanzania. LUCID Working Paper 25, International Livestock Research Institute, Nairobi.

[14] Olson, J.M., et al. (2004) The spatial pattern and root causes of land use changes in East Africa. LUCID Project Working Paper 47, International Livestock Research Institute, Nairobi.

[15] William, C.M.P. (2003) The implications of land use changes on forests and biodiversity; A case of the 'half mile strip' on mount Kilimanjaro, Tanzania. LUCID Working Paper Series Number 30, International Livestock Research Institute, Nairobi.

[16] Rowcroft, P. (2005) Gaining ground: The socio-economic driving forces behind decisions regarding land use and land use change. An overview. Working Paper 16, Vientiane.

[17] Gwambene, B. (2007) Climate change and variability and adaptation strategies and its implications for land resources in Rungwe District, Tanzania. A Master of Science Dissertation, University of Dar es Salaam, Dar es Salaam.

[18] Kangalawe, R.Y.M., et al. (2005) An analysis of land use dynamics and land degradation process in the great rift valley, Central Tanzania: A case of Iramba District. OSSREA Publications, Addis Ababa.

[19] Majule, A.E., et al. (2013) Impact of climate change on natural resources and community livelihood in Tanzania: Experiences from semi arid areas of Tanzania. Transworld Research Network, Kerala.

[20] Majule A.E. and Mwalyosi, R.B.B. (2005) Enhancing Agricultural productivity through sustainable irrigation. A case of Vinyungu farming system in selected zones of Southern Highlan, Tanzania. In: Sosovele, H., Boesen, J. and Maganga, F., Eds., Social and Environmental Impacts of Irrigation Farming in Tanzania: Selected Cases, Dar es Salaam University Press, Dar es Salaam.

[21] Kassian, L. (2012) Socio-economic and environmental implication of valley bottoms farming as adaptation strategy to climate change: A case of Mufindi District in Iringa Region. M.Sc Dissertation, University of Dar es Salaam, Dar es Salaam.

[22] Kaijage, H.R. (2012) Impact of climate change on groundwater dynamics in Nzega District, Tanzania: Triangulation of indigenous knowledge and empirical method scenario analytical approach. M.Sc Dissertation, University of Dar es Salaam, Dar es Salaam.

[23] Rowell, D.L. (1994) Soil sciences: Methods and applications. Longman, London.

[24] Nelson, V. and Stathers, T. (2009) Resilience, power, culture and climate and new research directions: A case study from Semi-Arid Tanzania. Gender and Development Journal, 17, 81-94. 